Vol. 20, n² | 2016

Varia

\title{
Dissecting Jack-the-Ripper : An Anatomy of Murder in the Metropolis
}

\section{Elizabeth Hurren}

\section{(2) OpenEdition \\ 1 Journals}

Electronic version

URL: http://journals.openedition.org/chs/1667

DOI: 10.4000/chs.1667

ISSN: 1663-4837

\section{Publisher}

Librairie Droz

\section{Printed version}

Date of publication: 1 December 2016

ISBN: 978-2-600-01953-8

ISSN: 1422-0857

\section{Electronic reference}

Elizabeth Hurren, "Dissecting Jack-the-Ripper : An Anatomy of Murder in the Metropolis », Crime, Histoire \& Sociétés / Crime, History \& Societies [Online], Vol. 20, n² | 2016, Online since 01 December 2018, connection on 10 December 2020. URL : http://journals.openedition.org/chs/1667 ; DOI : https://doi.org/10.4000/chs. 1667

\section{This text was automatically generated on 10 December 2020 .}

(c) Droz 


\title{
Dissecting Jack-the-Ripper : An Anatomy of Murder in the Metropolis
}

\author{
Elizabeth Hurren
}

\section{Introduction}

1 In 1888, the true identity of Jack-the-Ripper confounded the Metropolitan Police of London and created a publishing sensation that has turned into a global industry of true-crime genre. ${ }^{1}$ Numerous armchair detectives have speculated about the identity of the serial killer, the motivation for the murders, as well as the precarious lifestyles of the five iconic female victims, and their poverty setting in the East-End. Paul Begg is one of a number of modern commentators who have recently concluded: "the identity of Jack the Ripper isn't really very important. It's the story of those crimes and the women who died and of the society and times in which they lived that matters and that holds the enduring fascination". ${ }^{2}$ This article builds on this observation by returning to the shadowlands in which the main victims lived and worked, re-examining what their personal connection to Jack-the-Ripper may have been. Whilst it may never be possible to name Jack conclusively, it is feasible to look with renewed historical efforts as to how it was that this serial killer was able to evade detection, and why he was motivated to murder his chosen victims. Rediscovering Jack involves walking along a notorious road called Dorset Street in the East-End of 1888 with fresh historical eyes, and to do so with a contemporary medical mind-set. It will be shown that this street-scene, connecting together almost all the murders, provides vital clues about a secretive trade in the dead that may attest to Jack's real cover story and deadly disguise for murder. In so doing, a new historical context, never considered before, has potentially wide-ranging application for future research into crime studies that are of interest to an international audience. We begin therefore in Sections 1 and 2 on Dorset Street by revisiting its urban street-design looking carefully for medical clues that have been missed or misunderstood in standard historical accounts. Section 3 then dissects Jack's anatomical skills, and the forensic features of the 
murders in the light of the new medical information introduced. This, it will be argued, facilitates a cold case review. Section 4 builds on that revisionist approach by concentrating on the medical fragments of the fifth murder victim's life. It will be argued that Mary Jane Kelly's killing could have been crucial to the social camouflage of Jack. Attention is paid to her links to the others murders, including Mary Ann Nichols, the first victim, whose connection to Dorset Street was not obvious at the time and therefore requires historical scrutiny. This article's anatomy of murder in the metropolis is, hence, all about dissecting Jack-the-Ripper's medical disguise to expose his dreary but deadly cover story to public scrutiny for the first time since the late-Victorian era.

\section{Death on Dorset Street : Remapping the Medical Scenery}

2 The term 'East-End', as the name implies, has been used to describe an area of the capital city that runs eastwards outside the medieval wall of the old City of London, down towards the large docks north of the River Thames. In Victorian times it became synonymous with derogative slang, 'the blackspot'. Charles Booth in in his Life and Labour of the London People called it a place of "misery, vice, and a cesspool into which the most degraded had sunk". ${ }^{3}$ The East-End was filled with parishes in which economic deprivation was deep. ${ }^{4}$ It was riddled with death, dearth, and disease, where criminal activities of all descriptions defied the rule of law. Popular penny-dreadful novels of the period often featured sinister characters walking its streets. These were dangerous assailants, the vicious and semi-criminal. Few denied that the dirty slums were crisscrossed by a dense network of alleyways, courtyards, and poorly constructed lodginghouses that fronted brothels. Over-crowding was common and life-expectancy low. The East-End certainly had a distinctive street-culture of bar brawls and prostitutes fighting to protect their pitches. Most nights, rough justice broke out on nearly every streetscene. The presence of so many large workhouses - at Lambeth and Whitechapel in particular - located next door to imposing infirmaries along the Mile End Road symbolised inescapable destitution..$^{5}$ At the life-cycle crises of birth, in pregnancy, and old age, few of the poorest had any money for basic healthcare. Poor Law institutions became a last resort call in the makeshift economy of the labouring poor. ${ }^{6}$ For others, two doubledip recessions in 1876-1884 and again in 1893-1895 caused employment levels to plummet, cheapening piece-labour, and reducing wages below subsistence levels. During the 1880s, the East-End was not somewhere from where it was possible to work one's way out. The area was one huge poverty trap. Those who fell from relative poverty to absolute poverty could never hope to reverse their dire economic plight. If Jack-the-Ripper wanted to get away with murder, then in the East-End there were plenty of potential female victims living very vulnerable lives on the outer margins of respectable late-Victorian society.

3 All commentators on the Jack-the-Ripper case files agree with Paul Begg that : "It has to be acknowledged that Dorset Street features prominently in the story of most of the victims". . At least four of the five iconic fatalities known to have been brutal murders committed by the same serial killer happened along this street-scene and this is therefore a location that merits being revisited with fresh historical eyes. Before embarking on a sight-seeing tour of the street-scene, there are three things that need to be kept in mind. Firstly, there was something about this street-scene that a murderer like Jack valued 
highly and which crime historiography has failed to locate. The killer (as we shall see in Section 3) was very methodical about homicide. So it is unlikely that the murder site was chosen without careful consideration. Secondly, the street-scene was once very familiar to contemporaries, too familiar perhaps, because something was taken for granted about aspects of its urban design that crime historians still need to engage with. The street furniture and its social wallpaper merited closer scrutiny by the Metropolitan Police who may have been blind-sided by the obvious too. It is therefore necessary to look carefully again at the normal layout of buildings, social spaces, and public areas. New clues as to any unwitting features will reveal how it was that a serial killer was able to blend in with the surroundings. A third observation is that to evade detection the killer must have looked non-descript, and been part of the social fabric of the community setting, so much so that nobody gave them a second glance, or when questioned they had a convincing explanation for their presence in the area. As it was essential to beg, borrow, or steal, to pay for a bed for a night in the over-crowded lodging-houses along the street-scene, the serial killer either had the resources to maintain a disguise, was hidden by someone, or earned money in such a way that it provided the perfect cover story. Crime and medical historians need therefore together to remap the most mundane street features that facilitated murder on Dorset Street.

4 Imagine then standing at the top of Dorset Street in the East-End of London in 1888 (Image 1, appendix). ${ }^{8}$ It was a busy, dusty thoroughfare, about 133 yards long; narrow, littered with run-down terrace-houses, broken windows, and cheap curtain material flapping in the wind. The brickwork was stained by coal dust and there were rough cast stone-steps ; privy yards stank with animal urine and human faeces. The pits containing food waste left a permanent brown slug of decaying matter lying torpid in the road. It was not simply a health hazard to venture out of doors but an assault on the five senses too. Few walked alone because physical loneliness was rare. Large lodging and doss houses emptied each morning (Image 2, appendix). It has been estimated that these contained 700 beds along the street. Generally up to six people slept in one bed, with as many as thirty beds containing one hundred and fifty people per house. Dossing down cost on average $2 \mathrm{~s} 6 \mathrm{~d}$ a night ; from these calculations historians have concluded that about 1500 people walked up and down Dorset Street on a daily basis seeking accommodation. ${ }^{9}$ Old photographs suggest that this was not an exaggeration (Image 3, appendix) because Dorset Street was a human cauldron of the marginalised. Most people spilled into the crowded courts running down alleyways that contained a narrow seam of humanity like Miller's Court, a murder site, densely occupied each night.

In a normal working day, prostitutes plied their trade at three local public houses in the street: the Britannia, the Horn of Plenty, and the Blue Coat. The first had $a^{10}$ sign resembling that of a barber's shop, and later we will be revisiting this medical symbolism. Meantime, sex trafficking was a daily feature of life. Hiring a bed was costly and personal privacy was in short-supply, so prostitutes used the walls of the alleyways and privies of the open courts for their paying customers. Seldom did they sprawl down on the street flat on their backs because it would have exposed them to the police and they might have been physically stamped on by numerous passers-by or attacked by criminal gangs.

6 Most sex workers (females and males) preferred to perform oral sex in an alleyway turning a quick trick, avoiding penetration, and thus trying to reduce the risk of a contagious sexually transmitted disease. ${ }^{11}$ This had the added advantage of placing the prostitute within ear-shot of any fellow street-walkers, each looking out for the other's 
personal safety : those desperate for cash knew the common risk of domestic violence or a client running off without paying. Few could afford to be silent, with singing or whistling by sex workers a sensible habit when picking up a client. Generally all learned to be street-wise fast or they did not survive the prostitution trade for long; in middleage many were found dead in the street from alcoholic poisoning having drunk to excess to inure them to the bitter cold and very rough life-style. It is then one of the most curious features of the Jack-the-Ripper murders that those females used to handling big rough dock workers became so vulnerable to a violent man who initially at least did not instinctively frighten them or raise their hackles to call for help. Jack's advances must have been friendly in some respect to make them a lot less wary. The medical clues are back along Dorset Street.

Looking today at Dorset street's landmarks in Map 1 (appendix) it is easy to take for granted that there were three ale outlets, large lodging-houses, a big convent and night refuge, church graveyard, and inner courts, making up the architectural scenery; of which the most renowned became Miller's Court where Mary Jane Kelly was murdered in November 1888 (Sketch 1, appendix). Nothing seems out of the ordinary about this spatial urban design to the modern onlooker. Yet, these architectural features all had something in common, once very familiar to contemporaries, which have been neglected by crime historians. Each venue was a place where it was possible to once buy a dead body and body parts for sale under the Anatomy Act (1832). ${ }^{12}$ It is this medical perspective that needs to be factored into a cold case review.

\section{Medicine and Murder}

8 When the Medical Act (1858) came into force it set new standards in human-anatomy training for medical students. ${ }^{13}$ This was then expanded after the Medical (Extension) Act (1885) decreed that all trainee doctors, and those studying to be surgeons, as well as midwives, had to undergo a standard training in human anatomy to register to practice with the General Medical Council. This involved each student dissecting not less than two whole cadavers over a two year teaching cycle at a designated medical school next to a large teaching hospital. If those seeking to enter the medical profession could not get a whole body then candidates being examined were permitted to dissect enough body parts to make up their two complete cadavers, provided they did so within twenty-four months of starting their official training programme in human anatomy. Once then the number of medical students increased six-fold during the Victorian period, there was an urgent need for more dead bodies to dissect. This gave rise to a network of body dealers across the capital city that staffed the business of anatomy in the larger medical schools. The majority of body dealers were paid by anatomists like those at St. Bartholomew's Hospital, Guys Hospital and the London Hospital in the East-End. They all competed for body supplies and targeted areas of destitution where the poorest congregated in the biggest numbers.

The Anatomy Act stated that those who died in abject poverty in Poor Law institutions and whose families could not afford a pauper funeral must repay their welfare debt to society in death..$^{14}$ The poorest thus became the staple fare of the dissection table. Their bodies were to be sold if 'unclaimed' for burial by guardians of the poor in places like the Holborn, Lambeth and Whitechapel infirmary-workhouses to supply the needs of medicine. As however the life expectancy of paupers in some parts of the capital started 
to improve because of better diets, state intervention in sanitation, and improved notification of infectious diseases, the medical profession had to widen its network of body suppliers across the very poorest parts of London. The East-End became then a body-broking business by the 1880s, and typically most dealers worked from three types of premises that feature along Dorset Street. Nightly, they bought bodies found dead in the street. These tended to be carried to local public houses to make a body deal. They were put inside a large wicker laundry basket with soiled linen on top and wheeled by morning to the back of a nearby hospital where it looked like clean bedclothes were being returned for fresh delivery. In reality, inside the basket was a valuable anatomical sale. Body dealers also on a regular basis purchased the dead at the back doors of doss, brothels and lodging houses, making a quick profit for the owner. Profitable sales were also transacted at Night Refuges and Convents where fallen women secured midwifery services for unwanted pregnancies, miscarriages and spontaneous abortions. If they were turned away from charitable care they generally went to workhouse-infirmaries as a last resort, having tried to avoid them because of the stigma of shame and resentful of being under official surveillance. In other words, Dorset Street, described as "the worst street in London" for crime and poverty - a place where you could "do as you please" - had fit-forpurpose premises to run an ideal body dealing business in $1888 .{ }^{15}$

Not less than 60, 000 dead paupers entered the chain of supply from 1832 to 1929 across the capital. ${ }^{16}$ The dissection registers of St. Bartholomew's hospital by way of example record a body deal every night in some part of the East-End by 1888. Dorset Street was the medical centre of a shadowy business, yet one so familiar and mundane, part of the social fabric, that it went unnoticed by the police, witnesses, and newspaper reporters involved in the Jack-the-Ripper moral panic. It is then a striking feature that in each of the five wellknown murder cases someone stepped in and arranged to bury the women in a proper wooden coffin in a marked grave. For this area, under normal circumstances, that would have been a very unusual occurrence: a theme Section 4 elaborates. Females, their stillbirths and miscarriages, were prized dissection subjects, commanding high supply fees, and were afterwards buried by medical schools at cost in very large public graves using a recycled parish coffin. If, as the forensic evidence strongly suggests below, Jackthe-Ripper had medical skills then the body business of anatomy was a perfect cover for his deadly activities, and Dorset Street would have camouflaged his dealings.

11 The body dealing business depended on a lot of petty cash payments being handed out in a complex human chain of supply every night. ${ }^{17}$ Generally an 'undertaker' - a convenient label to disguise a body dealer at work - had a number of support people in their personal employ. This might include the staff of the local mortuary or dead-house connected to a workhouse. At the infirmary next door, porters and nurses often agreed for a few pennies to alert a body dealer when a pauper died from an infectious disease, unfortunate accident, or pregnancy complication. It was also the case that limbs which had to be amputated following operative surgery entered the chain of dissection supply. Body parts were in fact highly profitable transactions. Breaking up a body generated more sales, compared to trading a complete cadaver for a single fee. Most medical misfortunes were thus an opportunity cost for those training to be a doctor and they helped to create a flourishing body business in the East-End of 1888 .

12 It follows hence that most body dealers had business partners or close accomplices of one sort or another. Again the dissection registers of St, Bartholomew's Hospital show that a number of trusted intermediaries were employed on a regular basis. Generally the system 
worked by one of the demonstrators in anatomy having kept a careful tally in the body supply register of the poor person sold on for anatomy. Their age, gender, where they died, at what time, and who did the deal transaction were carefully noted. This was to satisfy the coroner in case of any query that there had been no foul play involved in the body purchase ; that is, the supplier was not murdering for profit. ${ }^{18}$ Usually once a month, the number of bodies that had been sold was tallied up. Then the main supplier was paid in cash for their work ; with the supply fees charged to medical students every quarter. Both men and women staffed the business of anatomy for the simple reason that prostitutes in the East-End preferred to deal with females they knew on the street and not strangers who might report them to the Metropolitan Police. For, whilst it was legal to supply a body for anatomy it was illegal to profit personally from a body transaction however abject the poverty. It made sense therefore for a body dealer to employ a small network of trusted people, located conveniently across a district to maximise business opportunities. It is this medical information that merits closer historical scrutiny in the Jack-the-Ripper story and the obvious body dealing premises along Dorset Street. Before doing so however it is essential to examine the homicide techniques in more medical detail. These will establish what sort of medical credentials Jack may have had and reveal the extent of his potential involvement in the business of anatomy.

\section{Dissecting Jack-the-Ripper's Anatomical Skills}

13 To be a body dealer required physical strength. Corpses had a dead weight that had to be lifted in and out of large wicker laundry baskets. ${ }^{19}$ All dead bodies traded were either in a physical condition known as primary flaccidity in the first hours after death or in rigor mortis for those found more than four hours following a street-fatality. If the deceased was a large-boned man or woman found in a lodging house bed, then it might be more practical to break the limbs to be able to lift them outside and fold the body into a wheelbarrow. Whatever the physical state of the deceased when discovered, it was necessary to be able to transport them efficiently under the cover of night or at first light to avoid any bad publicity. Those that sold them on wanted them removed as quickly as possible. This avoided the shame of being seen to do a body deal when someone could not afford a pauper funeral. Those in abject poverty had to be pragmatic and were not necessarily sentimental about selling the dead. A nearby medical school would bury the human material on their behalf at cost after dissection, and they would be able to spend the supply fee on subsistence, but even so, a speedy transaction reflected cultural sensitivities about the need for a 'good send-off' in the East-End. If Jack-the-Ripper had any involvement in the body dealing business of Dorset Street, that would have been a very good and normal cover story for the area.

Body dealers were very familiar and often sympathetic figures on the streets of the EastEnd. Serial killers are however not known for their human empathy and people skills. Jack would then, if he adopted body dealing as a cover story, have had to develop the art of small-talk because it was necessary to strike up a conversation to secure a transaction. The normal exchange itself was though often formulaic and somewhat perfunctory, with the body dealer appearing to be friendly-looking and conveying caution in their body language. By way of example when a body dealer named 'Ward' posing as an 'undertaker' traded the corpse of "Patrick O'Brian, male, aged 66, who died in St. Giles and Bloomsbury Workhouse on 27th October 1887" the deal was made with a nod and handshake at "7pm 
on the 29th of October" in person with mortuary staff. ${ }^{20}$ On arrival at the back of St. Bartholomew's Hospital later that night, the body was found to be missing a limb - " 1 leg amputation, left" wrote the anatomist on duty. After dissection, the cause of death was described as "senile decay and paralysis" attributed to a rough lifestyle of hard labour at the docks where the pauper may have experienced an occupational accident. Similarly when Mary Beckett (55) and Elizabeth Murphy (67) died at the Mile End Infirmary on the 13th and 14th March respectively, a body dealer named 'Slade' arranged to discretely collect their bodies for sale on "16th March 1888 at $6.15 \mathrm{pm}$ " from the mortuary attendant who was paid a supply fee. Both females were down on their luck and found to be suffering from "bronchitis" after dissection: a very common disease of poverty in the East-End. ${ }^{21}$ The anatomist on duty noted that he could not send "notice to an address" that was permanent because both women were street workers, in all likelihood prostitutes.

curious coincidence the same dissection registers also record the sale of a pauper named "Mary Kelly aged 69, female, body number 34 of the anatomy season 1888-9". ${ }^{22} \mathrm{Her}$ corpse was purchased from "Holborn Union workhouse in St. Luke's parish" by one of the most active body dealers in London on "7th December 1889 at 8pm". Her cause of death had been a painful decline from "dropsy [swelling from water retention], chronic bronchitis [making it hard to breathe] and emphysema [eroding the lining of the lungs]". Since however she was a female and her body was therefore prized, new preservation techniques with improved chemicals meant that she was retained for dissection for "112 days". She was finally buried in a large pauper grave on "25th March 1890 " at cost, by the demonstrator in anatomy on duty. So although it was a people business, those that made the most profits did so in few words with lots of reassuring facial and hand gestures : a half-smile, tender eyes, a squeeze of the hand on the arm, conveyed enough humanity to earn a death for sale. A serial-killer likewise needed to be able to lure his victims without causing panic, so whilst Jack had pathological personality traits these must have been kept in check to achieve his deadly ends. That context seems to explain why the later victims were not more wary as the killing-spree became more violent. Another credible possibility is that an accomplice took responsibility for the people side of the business of the body trade on Dorset Street, a theme Section 4 explores. Meantime generally body dealers dressed in black or dark clothes and had a non-descript appearance, with some carrying a medical bag containing basic dissection tools : traits reported to the police by witnesses who claimed to have glimpsed Jack in the vicinity. If a body dealer lacked physical strength then they might compensate for this by developing dexterity with the lancet. The most skilled could cut up each corpse with a sharp knife very quickly on the street-scene : again something that Jack seems to have been well-practiced at. Still, the body dealer would need assistance to push the basket or wheelbarrow as it filled up during the night back to the designated medical venue. It was essential to ensure that blood did not spill down the road and alert the police or coroner to the deal-making activities, accepted by the local community as a fact of life but taboo if exposed to public enquiry. In other words, the body business was all about double-standards and that may have suited a serial killer very well.

In all the Jack-the-Ripper homicide cases, there was a methodical manner of murdering the victims which had remarkable application for the body business of the East-End. For there has been considerable debate in crime historiography about whether 'Jack the Ripper ' was a medical man or not. ${ }^{23}$ Recent scholarship has focused on a spectrum of potential 
killers including those who worked in slaughter houses, farrieries with veterinary skills, and medical professionals connected to the police like coroners and surgeons with the right knife skills, all seen in the area of the murders. Solving the conundrum of who Jack might have been and how he could have evaded detection by the Metropolitan Police involves factoring in the anatomy trade. It was after all a forensic fact that each victim's neck was slashed within seconds. ${ }^{24}$ The murderer used a knife to make a sharp cut across the underside of the chin, a long incision from ear to ear. This first and fatal wound opened the carotid artery and Jack then effectively silenced each victim's voice-box. Only a person with a working medical knowledge of anatomy would have known where to cut with precision. Forensic evidence suggests that the murderer grabbed the women, cut their throats, and then eased the dying victim onto the street. In this way, they attracted as little attention as possible to the crime. It is noteworthy that fluids drained away fast, generally behind the victim's head. They may have been attacked from the front but the body was then placed back carefully on the ground or bed. Blood thus gushed out of the body from the neck area but did not spill onto the torso. The murderer was then free to dissect the corpse cleanly: a valued anatomical skill in an era when preservation techniques were crude. Each torso was also opened from the neck to the navel. In a frenzied but highly skilled attack the womb was cut open above the upper vagina area. This exposed the pectoral muscles. The organs were taken out undamaged, including the womb itself. On several occasions, limbs were disgorged too. What is intriguing about this method of killing is that similar bodies that had been mutilated in this way were sometimes brought into St. Bartholomew's hospital dissection room. Occasionally entries read "mutilated entirely", "some mutilation", "unsuitable for dissection, as mutilation", "body had been opened" and so on. ${ }^{25}$ Yet little historical link is made between the anatomy trade and the high-profile Jack-the-Ripper victims.

The Home Office, Metropolitan Police, coroners, and neighbours all speculated about the motive for such gruesome attacks. ${ }^{26}$ By common agreement, these were despicable murders committed with exceptional ferocity and speed. Unanswered questions included: how could anyone walk into crowded neighbourhoods where the poor lived cheek-by-jowl and with such confidence murder quickly and then make a swift getaway? It seemed reasonable to suggest that they may have had an accomplice. Speculation at the time was that the murderer was someone with basic dissection training. If so, then the anatomy trade could have been a factor in their murdering methods. The speed with which bodies were turned around at St. Bartholomew's explains where somebody attached to the body business might have learned to use the lancet with such lightning skill. How the murderer dealt with each victim's blood underscores this point. The crime scene was bloody but bodies were bloodless, a crucial forensic distinction. Mutilation was methodical and therefore based on some form of anatomy skill performed at high speed. To dissect a fresh body like this was a feat that could only be achieved with repeated practice. Medical students learned to work with basic equipment in cold candlelight or by gaslight ; it was often hard to find the main organs, much less cut them with anatomical precision. $\mathrm{T}^{27}$ he dissector had to know what they were doing on the dissection table. If they did not follow standard techniques, then the person on duty would be up to his armpits in plasma in minutes. Blood stopped coagulating after death but this did not mean that dissection was not in disarray. The stomach contents, festering food and blood, often flowed from fresh corpses cut by amateurs. The smell would have been overpowering and the corpse a bloody mess. If the body was kept for longer than two days, then preservation fluid had to be injected into the carotid artery. The blood was 
slowly replaced by chemicals. In cases where the body contained a baby, the dissector had to be highly skilled to be able to extract the dead infant undamaged from the deceased mother for teaching purposes. Whatever the circumstances in each case, the murderer who cut the victim's necks in the Jack incidents must have had a basic knowledge of what had to be done in the first hour on a dissection table when a fresh corpse was acquired for anatomy. It was not a skill that was learned arbitrarily from animal work or from human anatomy books. Jack had been hands-on somewhere, at some-time, to have been this skilled at cutting up the victims in fifteen minute short intervals without being detected.

Wynne Baxter, the coroner in Mary Ann Nichols' murder case, held an inquest that concluded on 26 September 1888 :

the injuries must have been made by someone who had considerable anatomical skill and knowledge. There were no meaningless cuts. The organ [upper pelvis area of the womb above the vagina] had been taken by one who knew where to find it, what difficulties he would have to contend against, and how he should use his knife so as to abstract the organ without injury to it. No unskilled person could have known where to find it or have recognised it when it was found..$^{28}$

Paul Begg points out that the Lancet agreed with this medical conclusion. Its editorial leader stated that the speed "pointed to the improbability of anyone except an expert performing the mutilations described in so apparently skilful a manner." ${ }^{29}$ Someone of a pathological frame of mind could then have been attracted to anatomical work that suited their disturbing personality traits inside the body dealing business on Dorset Street and the surrounding district of the East-End. In the autumn of 1888, that person or someone associated with the anatomy trade perhaps took basic dissection skills out at night with deadly consequences. Begg adds that the fact that most of the victims were street prostitutes, and their wombs subjected to a frenzied knifing attack, is not conclusive proof of a sex crime. This is an important observation if we factor in the anatomy trade and its fast turnover of prostitutes. In the anatomy season of 1888, women who worked in the sex trade were not in short supply at St. Bartholomew's dissection room for instance but the turnaround rates of all bodies had changed. Preservation techniques had improved and most corpses could be preserved with chemicals for longer than before. On average an anatomist had a maximum of 7 days to dissect a corpse up to the mid-1880s, then around 1888 the use of stronger preservation chemicals increased the time spent on each dissection to over 100 days. The problem was that each preserved cadaver now looked less than human. Anyone who preferred fresh, female corpses would have needed to seek them on the street. A basic alteration in preservation methods could have been behind the motive for murder, coinciding with the time when the Jack murders started in the East-End. Whether they had assistance is an open question.

It is worth reiterating that there were many intermediaries involved in the body business with a working knowledge of anatomy and dissection in the East-End. Body dealers were very familiar figures and included infirmary nurses, workhouse porters, undertakers, coroners' mates, and even midwives. "Ms. Biers", for instance, of "St. James' Workhouse" was listed as a female body dealer from the anatomy season of 1840 onwards in St. Bartholomew's dissection registers. ${ }^{30}$ The potential list of people involved in the body sales is extensive and throws up all sorts of unproven but intriguing possibilities; though why 'Jack' murdered for such a short period remains a mystery: a theme Section 4 returns to. Reviewing the surviving forensic evidence, one curious feature of the murder cases is that all of the female victims did not flinch when approached: as was stated above. Yet, as the murders went on, they would have been more wary of being solicited 
by a stranger. At the subsequent coroners' hearings, witnesses testified that some victims had to risk their personal safety for paid sex to survive outside the workhouse. Others needed a few shillings for a lodging room for the night, offering oral sex in an alleyway. Free drinks at the local public house motivated some to walk the streets. They all nonetheless were on the lookout for danger, more sensitive to unusual advances. Several women had also been in and out of Holborn, Lambeth, and Whitechapel workhouses. They were well known to the police and poor law authorities, knew a wide cross-section of the population, and were streetwise. The forensic report in Mary Ann Nichols' case, by way of example, stated that her petticoat was marked with 'Lambeth Workhouse P. R.', a pauper stamp. ${ }^{31}$ Nicols had been treated at the workhouse infirmary on a regular basis. This observation is noteworthy because all the female victims were left in a rather unusual physical pose of some relevance to the medical mystery surrounding events and the possibility of an accomplice.

Begg explains that the women were found flat on their backs: "the legs were drawn up, the feet were resting on the ground, and the knees turned outwards" ${ }^{32}$ In the past this was how anatomists dissected to expose the major muscles. It is also the standard medical position when a woman is having a smear test, or internal physical examination to check progress in childbirth. Yet crime historiography seldom discusses the possibility that a woman made the first initial approach, not a man. This would explain a lack of circumspection in all the cases. Maybe an intermediary known to the victims, someone who traded for instance in their stillbirths, whom they were used to acting as a gobetween, made the first fatal move. The actual attack had to be done by a man because of the physical strength needed to carry it out with such ferocity and quick skill. That, however, does not rule out the possibility that the women were groomed by a female accomplice, familiar to them from a workhouse infirmary or with whom they had done body deals on the street. Surviving dissection records confirm that women dealers and male traders walked the physical streets of Whitechapel in 1888 . The ending of a supply partnership between like-minded individuals prepared to murder, might explain why the killings stopped as abruptly as they started. To engage with this explanation it is necessary to focus on the fifth murder victim Mary Ann Kelly who died in Miller's Court off Dorset Street because her personal circumstances hint that she may have been the missing accomplice to Jack-the-Ripper in 1888. This may be unpleasant to think about but it does merit careful consideration.

\section{Mary Ann Kelly : Innocent Victim or Body Dealer?}

When the mutilated body of Mary Ann Kelly was discovered in Miller's Court off Dorset Street in the early hours of the 9th November 1888 it was a shocking sight even for the Metropolitan Police officers who by now recognised Jack-the-Ripper's killing-style. ${ }^{33}$ Kelly, the fifth iconic victim, had been murdered with an exceptional level of sustained violence. Her face was attacked with a knife in a vicious frenzy, and her breasts had been severed from her torso. Her lower limbs looked like a dissected cadaver, and her major organs like the heart had been removed. Her inquest report was distasteful and disturbing even for the hardened medical men present used to doing post-mortem work. Evidently the serial killer was angry, brutal, and unforgiving. Crime historians have long speculated as to why Kelly was singled out for such callous aggression and why there was so much blood shed on the bed she slept in. Either this was the culmination of 
pathological cruelty that had been building up to a crescendo of violence, a feature of some serial killings, or there was another motivation for the murder that the evidencegathering never uncovered. To engage with the latter it is necessary to examine Mary Jane Kelly's personal circumstances and to do so by factoring in the body trade that was flourishing along Dorset Street in 1888.

In 1973 a six-part BBC documentary called Jack-the-Ripper revisited the crime scene of Dorset Street. As part of the preparation for the series, the research team spent a great deal of time trying to locate anyone who had once lived in the area or knew someone that did. This included the bar staff and drinking clientele of the three public houses on location, anyone that had once used or recalled knowing people that had hired a bed in one of the street's large lodging-houses, as well as practicing Catholics that had staffed or supported the charitable work of the Providence Row Night Refuge and Convent that once faced down Dorset Street. In a curious interview, one novice who had trained at the Convent in 1915 recalled that an older nun who had worked on the premises in 1888, told her : "If it had not been for the Kelly woman none of the murders would have happened". This Paul Begg points out is "hardly reliable testimony" but nevertheless he concedes that it was an "odd comment" for a Christian nun of devout principles to have made about the Jack-the-Ripper murders. ${ }^{34}$ The substance of the oral testimony might however make perfect sense if one factors in an active body trade in the street and one to which some residents might have once been connected: something substantiated by St. Bartholomew's hospital dissection registers. The evidence connecting Mary Jane Kelly to that business across other London teaching hospitals in the area is currently circumstantial but it might become more convincing once historians re-examine fragments of her personal story that may have been misread or misunderstood.

Mary Jane Kelly was a twenty-five year old female of Irish descent said to have been about " 5 foot 7 inches tall and of stout appearance" in 1888. She had a pleasing countenance of "blood hair, blue eyes, and a fair complexion" that framed her "attractive face." ${ }^{35} \mathrm{Few}$ doubted that she was friendly and approachable. Others remarked that as a child she had migrated to Wales with her close family, learnt to speak fluent Welsh, and married a collier named Davies when she was sixteen years old. After he was killed in an explosion, she moved to Cardiff, resided with a cousin, and may have turned to prostitution to earn her keep. By all accounts she suffered from ill-health and lacking the financial wherewithal for medical care she entered the Cardiff infirmary to get treatment. By the time that she arrived in London in 1884, she was living in relative poverty. It was in this economic condition that she lodged with the Nuns of the Providence Row Night Refuge facing down Dorset Street. If as a former nun claimed she had a personal connection to Jack-the-Ripper it may have begun at this formative time. The body dealing trade was often associated with charities that gave people down on their luck a bed for the night and food from the soup kitchen in the coldest winter months. It was not a place of last resort like the workhouse but it was somewhere to hide from the shame of poverty for those that had fallen on hard times. The Refuge on Dorset Street has thus been described as providing "shelter for 140 men and 112 women as well as being a training home for servants." ${ }^{36}$ It was "open in winter from 5.00 pm onwards, from November through to the following May" and described as accommodation "of the simplest kind, and in fact inferior to that provided by many casual wards" of local workhouses. One of its charitable aims was to house "girls who had been saved from vice" and "deserted women cheated in the promise of marriage and flung friendless on the world". Mary Jane Kelly, young 
widow, former prostitute, possibly from a Roman Catholic background in Ireland, had a typical charity profile. Inmates like her were generally housed for "six weeks" and given some practical assistance "in the form of tools for artisans, clothes for servants, and fresh goods for fruit and flower sellers". The Refuge tried to help people to get back into work to start earning a decent living. But of course, this was also a place in which people lost heart and failed at life. In death, they were in destitution with nobody to pay for their pauper funeral. In other words, this was an ideal location to encounter body dealers and their accomplices on arrival in the East-End. Providing for the possibility that what the nun claimed to her novice in 1915 was correct, Mary Jane Kelly may have encountered her killer in 1884, four years before she was killed, and there may have been a connection to the Refuge, as well as the other murder victims in the vicinity. Something she did or said here would prove to be her, and others', fatal undoing.

There are a number of personal descriptions attached to Mary Jane Kelly that should be considered in the light of the body business. It was common for those involved to use a number of aliases, and indeed all the five female victims did this in their hazardous lives as a matter of course. So resorting to an alias does not prove they were involved as gobetweens in body sales but rather that their life-styles were compatible with the modus operandi of an accomplice to the anatomy trade. Yet, Kelly went further than the rest of the victims and altered her name from English to a French spelling: Mary Jane Kelly became Marie Jeanette Kelly. Her former live-in lover, Joseph Barnett, a porter at Billingsgate market and fruit hawker, told the police that after she left the Refuge facing Dorset Street, Kelly told him that she became a prostitute in Knightsbridge. In the West End she was one of a number of young, pretty girls that may have been procured by highclass madams. Kelly told Barnett that she worked for an unnamed French lady that ran an upmarket bordello, and this was why she changed her name because she visited Paris on a couple of occasions and rode in smart carriages with upper-class men. It was also later revealed by other witnesses at the time of her murder that she was 'well-educated' enough to be able converse with wealthier male clients, may have been an "excellent scholar" (though in which respect was not revealed), and was known as "an artist of no mean degree." ${ }^{37}$ Most people said that "she was superior to that of most persons in her position." As crime historians have pointed out it is very difficult to balance this evidence against the popular image in the press of Kelly as a drunk down on her luck dossing in Dorset Street. Something does not add up. Either she was a fantasist and this possibility cannot be ruled out for someone who wanted a better life but was in abject poverty; or, the bits and pieces of her life do contain a kernel of truth but the context of the fragments was forgotten or overlooked in the distorted face of the dreadful forensic information. Here then the historian needs to rethink the potential gaps in the misperceptions of how a life was lived, to try to tie the threads back together in a cold case review.

The epicentre of anatomy and prostitution in the 19th century was Paris. ${ }^{38}$ The threads of Kelly's life look disparate until one appreciates this simple fact. In her life-story of a Tale of Two Cities perhaps Kelly was used to meeting medical men for sex in London on their return from Paris. If, despite the limited evidence, her connection to the French lady that ran a bordello was in fact her first entry point into a shadowy medical world, then her nemesis started to unravel a lot earlier than the police realised. It may have been this connotation that an older nun who had befriended Kelly in 1884 knew about, which troubled her years later. What is known is that after the French Revolution it was a civic 
duty for everyone alleviated by charity or the state to have their body dissected in the national interest of France..$^{39}$ Parisians were very open about anatomy and dissection, with the civil authorities having kept the public morgue open daily, located behind Notre Dame Cathedral, so that visitors could identify bodies before they were sent for dissection. It was also common for females to learn life-drawing by sketching the dead in anatomy rooms for a small fee. This tradition of anatomical art also happened in London too. It started with the Murder Act (1752) and continued after the Anatomy Act (1832) came into force. Some females ran the anatomical shows behind-the-scenes at medical museums along Fleet Street. ${ }^{40}$ They generally assisted with preserving specimens for medical use by helping to inject wax for model-making. Their dexterity was useful to avoid preservation chemicals spilling, extending the dissection time by inserting liquids through the carotid artery and the thumb: areas of the body that happened to be violently assaulted during Kelly's murder. They likewise acted as a liaison for illegal abortions procured at night from the backdoor of medical museums. Females that learnt the art of anatomy in this way were very familiar with placentas and major organs like the heart : the latter removed from the body during the fifth homicide in Miller's Court. On the whole women employed anatomically tended to do casual work but all had some sort of basic education, could draw, and looked respectable enough to avoid bad publicity. In other words if Mary Jane Kelly was involved in any respect with the business of anatomy in the East-End, the fragments of her life suggest she could have been so since her arrival in the capital in 1884, and changing her name to a French spelling was not a coincidence but a reflection of her connections to anatomy via prostitution: although this cannot be as yet proven from the scant evidence, the possibility cannot be ruled out either. Most psychologists stress that people that weave tales to compensate for a mundane existence often do so by picking up and refashioning fragments of their life that have a semblance in a reality. So rather than Mary Ann having a Parisian set of adventures, perhaps instead she had known a medical man that had solicited her for sex and offered her other paid work, giving her a more comfortable berth at a West End bordello. Knightsbridge did house lots of medics and medical students that trained in Paris and worked in the capital's big teaching hospitals. Looking at how she kept up appearances is instructive too.

Female body dealers needed to be able to identify themselves visually but with decorum in their dress sense on the street-scene. They typically wore one of two outfits : either a nurse's uniform with a white apron, or undertaking garb. This would always be cleanlooking and not pawned. The person had to appear to be generally in good health to be approachable, and have a stout constitution to handle the dead whatever their size and shape : perhaps this is one reason why all the chosen victims were stout. In Mary Jane Kelly's case witnesses said she seldom pawned her clothes, which was unusual for someone reported to be ' 29 shillings in arrears' at the time of her death: a cash-flow theme revisited later. ${ }^{41}$ Meantime, it was said she always looked clean and presentable, wearing most days : "a white apron [over] a black silk dress and often a black jacket". She was therefore said to be "shabby genteel in her appearance and approachable, having rather attractive features." For the Victorians, black was fashionable but prostitutes tended to wear something colourful to catch the eye of clients. So it is worth reflecting on the fact that Kelly's attire was more appropriate for someone attached to a body dealing business of some description than soliciting sex, which may also explain one of her alias's, "Black Mary" ${ }^{42}$ There was nothing odd about her demeanour if she needed to keep up appearances as an accomplice to a body dealer posing as an undertaker. Thus by way of 
example prostitutes on the Curtain Road of the East-End often sold their stillbirths to St. Bartholomew's Hospital via a go-between. It made sense to use a woman in the neighbourhood dressed in clean black to make the deals. They handled the cash payment, which could be anything up to a month's living wage for a female that died from sepsis (childbed fever) or more for her dead child : valuable commodities in the chain of supply. The deal-money would have been refunded once the 'undertaker' body-dealer had been compensated once a month by the medical school supplied. Perhaps this was why Kelly was " 29 shillings in arrears" but not unduly worried about the debt when she opened the door to her body dealer on the fatal night? It might also explain the throwaway remark that Mary Ann Nichols (victim one) made on the night of her death. At 1.20am in a lodging house in Thrawl Street she said she could not afford " $4 \mathrm{~d}$ for her bed" for the night, admitting that she had spent the money thrice over on alcohol. Witnesses said that she laughed this off saying: "I'll soon get my doss money. See what a jolly bonnet I've now got." 43 It is worth asking how exactly were these two sentences connected together; was a man footing her bill for a little black bonnet and why did he do this? Was it for sex - the obvious motivation - or had she just joined the ranks of a body dealer's business and the black bonnet was part of her new uniform that would help her pay her way? Another innocuous clue is worth considering here too.

In Image 4 (appendix) we see the archway entrance to Miller's Court on Dorset Street. To the right is a door at No, 26 to a shop in which a barrow and other items was kept. The police insisted on boarding up the property because local people were squatting in it for the night, and this can be seen in the photograph. It is also worth noting that the shop was opposite one of the three public houses in the street, frequented by Mary Jane Kelly. Indeed one of them, the Britannia, still had a barber's shop sign displaying its medical heritage of bleeding, teeth-pulling, and hairdressing. This was her patch and she knew the owner of the shop well, a man called John McCarthy who was also her landlord at No 13 Miller's Court. What is unclear and never seems to have been investigated thoroughly by the police is what exactly the 'barrows' in the shop were used for. ${ }^{44}$ We know that Kelly's body was carried away in a recycled parish coffin on a hospital cart that looked like a wheelbarrow but not what the shop barrows carried. Their innocuous nature was social wallpaper. Witnesses told newspaper reporters that the shop was known locally as "the shed", a space to doss down in if friendless females had no money for a shared bed for the night. Others hinted that McCarthy was a pimp; nevertheless, this tiny social space had two features necessary for the operation of a body trade. It may have been a rest room for those females out and about dealing on the streets, and it contained a crucial 'barrow' for transportation. If, as has been noted by many crime historians, nearly all the victims were connected to this set of rooms on Dorset Street, was 'the shed' their place to meet, get paid, and pass on their trades? And is this what the nun meant when she blamed Mary Jane Kelly for all the murders: was she the main accomplice who organised the other women at 'the shed' next door to her lodging room ? It would explain why the women did not flinch when first approached. Perhaps Kelly walked up to them at the front and Jack the body dealer grabbed them from behind? If so, she paid a painful price for, as she put it, "taking a wrong turn in life". As the Jack-the-Ripper murders continued everyone agreed that Kelly was a very frightened woman. Did their partnership falter and Jack then take out his anger in such a brutal fashion? If so that might bring together three crucial factors in any cold case review : emotional motivation, the means to commit such brutal violence, and the physical prowess needed to skilfully manage the opportunity costs associated with a high-profile homicide at a time of intense 
media coverage. Even so, there still needs to be a stronger link made that connects four of the iconic victims who had strong physical ties to Dorset Street (Annie Chapman, Elizabeth Stride, Catherine Eddowes and Mary Jane Kelly) to Mary Ann Nichols the first victim. ${ }^{45}$ Again the body trade may have united them in ways overlooked.

Looking at Map 2 (appendix) of the main locations associated with the Jack-the-Ripper homicides one thing stands out. All the buildings and murder locations were close to a main thoroughfare used by body dealers in the capital. They all clustered around a convenient road system. Though pushing a body in a wicker basket or wheelbarrow would have involved crossing from side streets like Dorset Street into the main road of Commercial Street, nevertheless with the latter's wider pavements and good road surfaces it was conveniently on a well-trodden route to the London Hospital up the Whitechapel Road. And, as we can also see, the first murder victim, Mary Ann Nichols, murdered on Bucks Row, died very close to this hospital venue. All body dealers preferred to adopt a route like this. In other words, what really links all five iconic victims is their geographic alignment within the body trade transportation routes out of the East-End. At a time when streets were stained with human effluent, a good road was essential to supply the needs of medicine.

Body dealers moved from workhouse to workhouse across their trading patches of the East-End of London. For Mary Ann Nichols this meant that she did not just enter random institutions. ${ }^{46}$ She was admitted to poor law facilities where the body trade happened to be thriving on the premises by the 1880s : notably at Lambeth in 1883, several in Holborn in 1887, the Strand in 1887 and finally Lambeth again in 1888. It is feasible that this may have been her first contact with Jack or an accomplice, even though she may never have guessed it at the time. One fact is certain, namely that the final month of Mary Ann's life was a sad one. In early August she entered Gray's End workhouse in one of the most notorious neighbourhoods of Holborn dubbed Little Ireland. It was a crime-ridden parish and the main poor law institution was the biggest supplier of dead bodies to St. Bartholomew's hospital. By all accounts, Mary Ann went back on the streets, was caught stealing clothes, and moved between lodging-house, doss sheds, and brothels. She accepted cash for sex, for as little as 3 pence, the price of a stale loaf of bread to eat, prostituting herself to get a shared bed for the night. Yet, the discovery of her body at 3.40-3.45am on 31st August 1888 on Buck's Row in the East-End shocked the neighbourhood. Someone that had frequented some of the roughest workhouses across London still aroused considerable sympathy for her plight; everyone agreed that nobody deserved to die in such a horrible manner. As the first iconic victim, she seems to have been a template for Jack's anatomical method of homicide, discussed in Section 3. She may have been a trial run, and this could explain why her connection to Dorset Street was not as obvious to the police as that of all the other victims. Mary Ann did not tend to live in lodging-houses and used poor law institutions much more frequently than the others. This would have made her personal interactions more erratic on the street. Ironically it may also have placed her at the front-end of the body trade happening every night in the dead-houses at the back of workhouses that she was staying in. As a servant employed briefly on the premises at Lambeth workhouse in 1888 she would have seen and known how all aspects of poor law life worked. Despite the medical mystery surrounding the reasons for her admittance to several infirmaries, during her time inside the premises body dealers were selling dead bodies of men, women, children and infants to Guys and St. Bartholomew's hospitals nearby. It would be very odd indeed if she had not known 
about the body trade in some respect. It is therefore conceivable that if Jack was involved in the body business in the area Mary Ann may have been his initial link in a human kaleidoscope of deal-making; perhaps she saw something that she should not have done as an onlooker drifting from dead-house to mortuary. Or had she simply dossed down at the shed of No. 26 Dorset Street one night and heard a conversation that should have been kept secret : we may never know.

\section{New Cover Stories: Murder in the Family?}

We conclude this article at a time when family historians are presenting new evidence on Jack's potential identity. Recently there has been considerable speculation that a pauper named Robert Mann, mortuary keeper for Whitechapel workhouse, may have been Jackthe-Ripper. Modern-day crime profiling, it is claimed, would expect a typical serial killer to have his life-story characteristics. In an intriguing book, Mei Trow, using modern forensic techniques, is convinced that Mann committed the murders because he had ample access to the dead, may have liked working with them, and got his hands on the first victim who was brought to him for safe-keeping. ${ }^{47}$ That he dressed and washed Mary Ann Nichols despite police instructions to the contrary before a post-mortem got underway was either, accidental, careless, or suspicious. The theory has received a lot of publicity but it has been criticised for lacking a convincing explanation as to why someone in a morgue might risk becoming involved in the crimes when under such intense police scrutiny. If one accepts that the police were aware of the operation of a body trade but ignored its day-to-day dealings because they were a shadowy fact of life in the area, then a serial killer would have effectively found the perfect cover story. It was common for the authorities to look the other way when informed of a dealing dispute. By way of example, Alfred Feist a workhouse master of St. Mary's Street Newington workhouse in the EastEnd employed Robert Hogg the undertaker (for which read body dealer) from Southwark on a regular basis. At the Old Bailey in 1858 Feist was charged with 64 counts of profiting from pauper bodies sold from the dead-house of the poor law premises he ran to Guys Hospital..$^{48}$ In 1858 he was found guilty but got off on appeal on a technicality. Essentially it was not in anyone's interest in the medical establishment in the locality to pursue the matter further because body dealers were a necessity. Meantime, Hogg went quiet for a time and re-emerged as a body dealer to St. Bartholomew's Hospital. And he had remarkable longevity since his so-called undertaking business remained connected to the medical school until the modern period. The body trade might yet then prove in a similar manner to be the solution to a missing historical context as to how the Jack-the-Ripper murderer remained hidden, calling for new and meticulous evidence-gathering. We need to know evidently much more about all those working in small morgues and dead-houses of workhouse-infirmaries connected to the murders, since Robert Mann was just one of a number of attendants on the dead that police encountered in the course of their enquiries. There were also several 'undertakers' who buried the victims and parish officers who charitably paid for the murdered women to be interred with dignity. Each and everyone one may have had a connection to the body trade and by implication Jackthe-Ripper.

We end this cold case review hence with the latest development. It has been claimed by a retired surgeon, Dr Wynne Weston Davies, that his near-relative named Francis Spurzheim Craig (1837-1903) was Jack-the-Ripper. ${ }^{49}$ Craig was a newspaper reporter 
covering the police court circuit at the time of the murders and it is claimed this may have been a useful social camouflage. Indeed documentary evidence has been found to suggest that Craig may have been the ex-husband of Mary Jane Kelly. It is postulated that she adopted an alias to disguise a failed marriage. Craig divorced a woman named Elizabeth Weston Davies when living at 306 Mile End Road in the East-End in the 1880s. The new book claims that Craig searched for Elizabeth (now called Mary Jane) who left the martial home after a brief marriage, turned to prostitution, and migrated to the EastEnd because her ex-husband resented her infidelity. She hence adopted various disguises to evade his detection. The new theory posits that the first four iconic murders were blue-prints for the fifth killing in 1888. Craig, it is argued, covered up his intentions by making it look like there was a serial killer on the streets. His real focus was to murder his ex-wife out of emotional spite. To do so, he learned how to evade police attention as a court reporter. This gave him the means to track down and then destroy Mary Jane's true identity. He murdered her in a brutal fashion to erode any potential links to him, smashing her face and mutilating the body. The extraction of the heart was hence a highly symbolic act : love turned to hate.

The difficulty with this turn of events is that it is a rather elaborate plot, even for a police court reporter to carry out. There would have been a lot of unpredictable events attached to the first four murders and no guarantee of escaping justice before being in a safe position to proceed to a fifth pre-meditated homicide. It does provide a motivation for murder but not the skilled means of killing anatomically, or the ability to stage-manage all of the logistical opportunity costs involved. There may however prove yet to be a macabre twist to this intriguing family history, for, Craig's middle name was the surname of a famous phrenologist, Johann Gasper Spurzheim. Craig had been fathered by Edward Thomas Craig (1804-1894) who became President of the Phrenological Society in 1888 the year of the Ripper murders : a noteworthy observation..$^{50}$ Since the time of the Murder Act in 1752, when criminals were hanged for murder and dissected, anatomy had become closely associated with the pseudo-science of phrenology. ${ }^{51}$ Indeed a 'Jack' was the term used for the pulley in dissection rooms to hoist up criminal corpses for brain study. An unanswered question is therefore whether the business of anatomy had some sort of close connection in the Craig family history? It may have pre-dated the Anatomy Act of 1832 (when criminals, not the poor, were subjects of the dissection table). Did Craig junior know about anatomy skills from Craig senior because a basic hands-on knowledge was handed down in his family-line? Phrenologists often attended criminal dissections and took plaster casts for posterity. If so, it would be a striking irony of family history for Dr Wynne Weston Davies, who in his career has specialised in human anatomy teaching and dissection, to have benefitted from the unsavoury side of medical advancement without knowing his potential connection to its long body trafficking history and phrenology. It is here that we need to leave open the dissection room door to the future research enquiries of crime and family historians. For the business of anatomy on the streets was social wallpaper, capable of concealing the most unscrupulous characters across the East-End of Victorian London. And in so doing, Jack may have had the method, motive and means to murder undetected in the Metropolis. 
Image 1

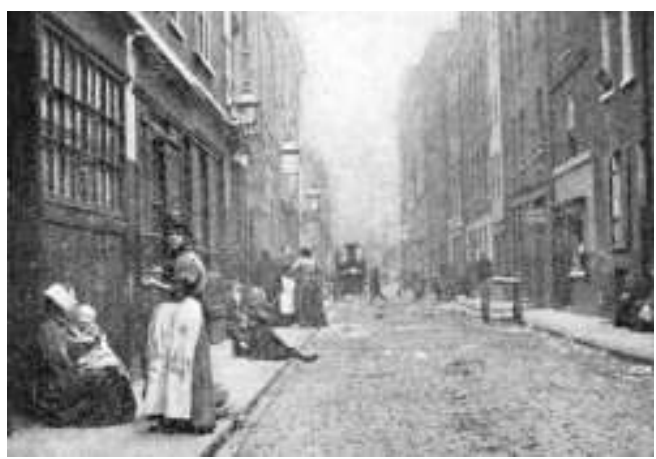

Dorset Street Map, 1888, Ordinance Survey, Whitechapel Division, first published by Her Majesty's Stationery Office, 1894. (No copyright clearance required for the map as more than 50 years since first printed).

Image 2

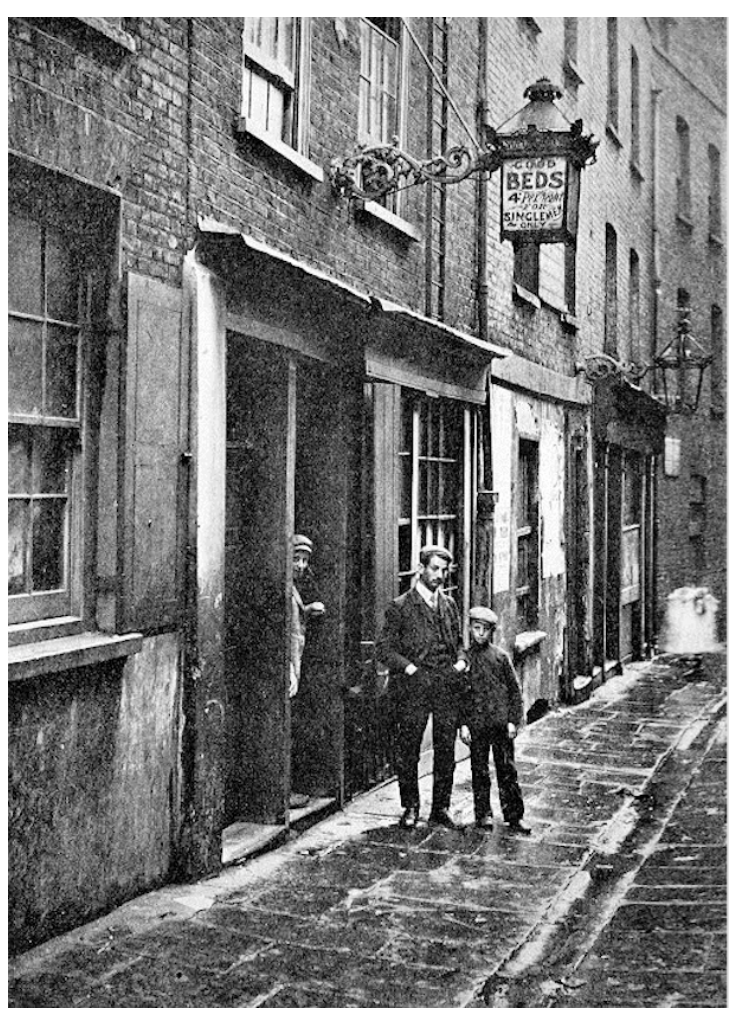

Photograph of a Common Lodging House sign in Dorset Street, 1888. (Copyright : Reproduced on open access at http://photos.casebook.org/displayimage.php?album=6\&pos=11_Attribution-Non Commercial-Share Alike 4.0 International (CC BY-NC-SA 4.0) creative commons license for academic purposes only). 
Image 3

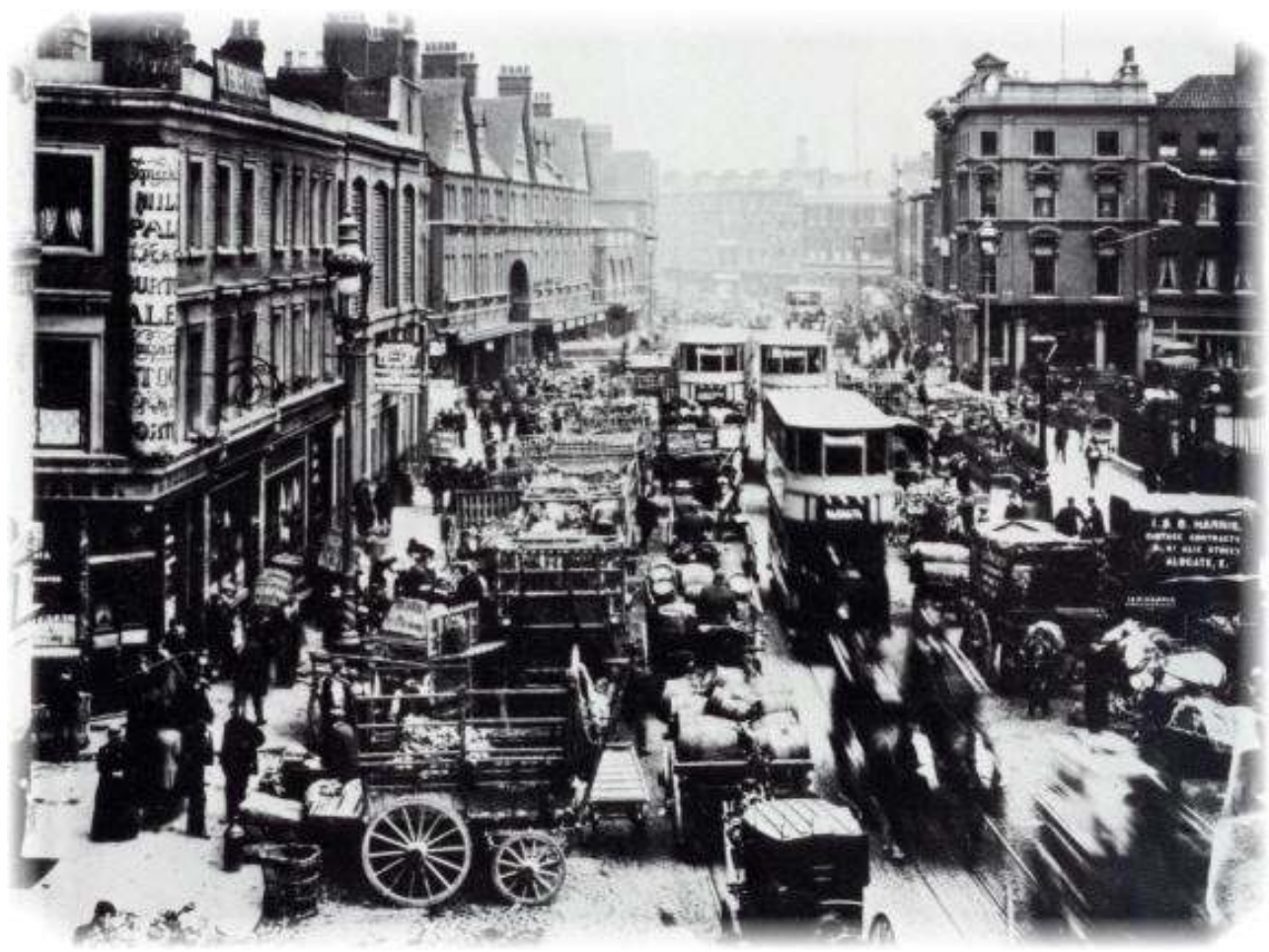

Dorset Street with the Britannia Public House on the left corner, c. 1888. (Copyright : Reproduced from an original photograph on open access at http://www.casebook.org/victorian_london/dst-pubs.html Attribution-Non Commercial-Share Alike 4.0 International (CC BY-NC-SA 4.0) creative commons license for academic purposes only). 
Image 4

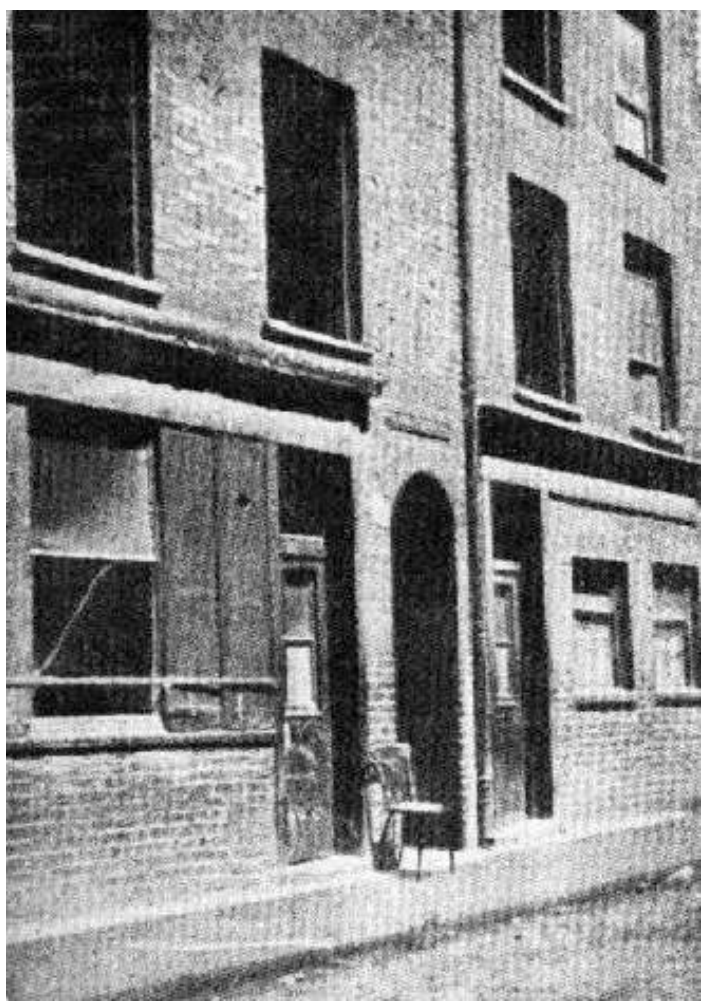

Image of the 'Entrance to Miller's Court in Dorset Street' first published by Leonard Matters, The Mystery of Jack-the-Ripper (London : W. H. Allen, 1929). Author Note : Through the archway is where Mary Jane Kelly was murdered. The door to the 'shed' is to the right of the archway. It was boarded up by the Metropolitan Police. No copyright clearance required as more than 50 years since first printed. 
Map 1

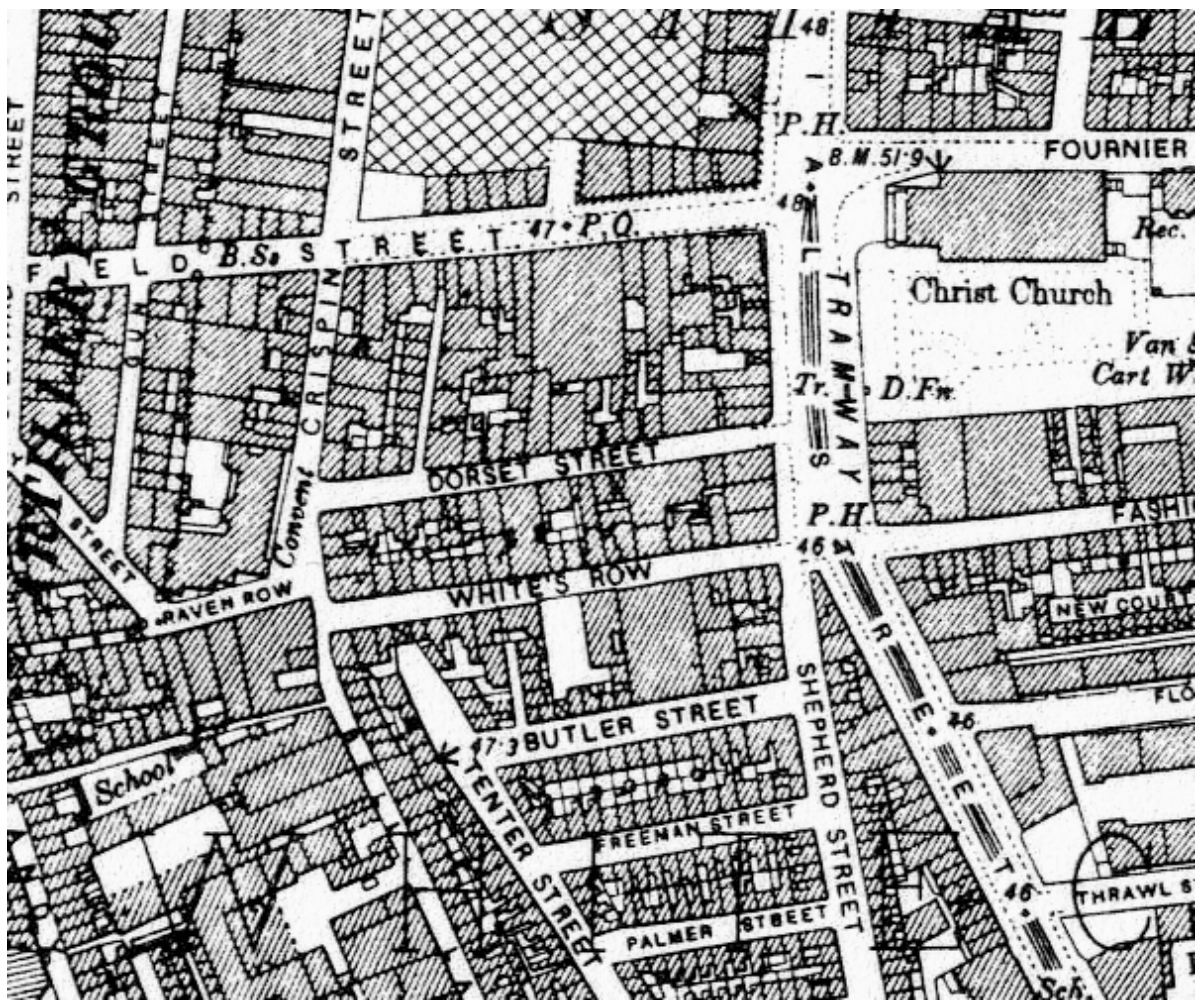

Dorset Street Map, 1888, Ordinance Survey, Whitechapel Division, first published by Her Majesty's Stationery Office, 1894. (No copyright clearance required for the map as more than 50 years since first printed).

Map 1 Key - designed by the author

Map $1 \mathrm{Kev}$-designed bv the author

0

Hom of Plenty Public House (5 Dorset S treet, northern end, cornered Crispin S treet)

9

Blue Coat Boy Public House (32 Dorset Street, next down the street, cornered New Court alley)

10 Street, pub of choice for Miller's Court residents like Mary Jane Kelly)

†

Providence Row Night Refuge and Convent, facing down Dorset Street (right

to left as you look at the map)

Jack-the-Ripper, Miller's Court (midway along the street) 
Map 2

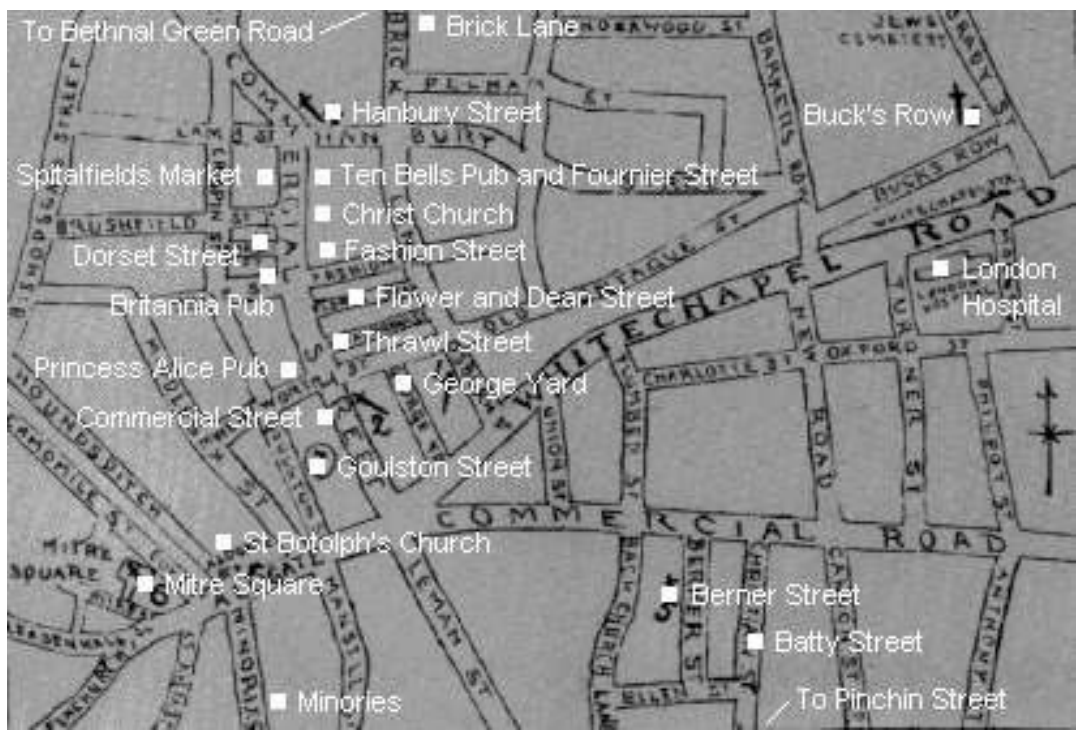

The East End of 1888 showing main major roads connecting across the East End to the London Hospital, 1888, reproduced from Ordinance Survey Map, Whitechapel Division, first published by Her Majesty's Stationery Office, 1894. (No copyright clearance required for the map as more than 50 years since first printed. Copyright on addition of place names added at http://www.casebook.org/ victorian_london/sitepics.html, Attribution-Non Commercial-Share Alike 4.0 International (CC BY-NCSA 4.0) creative commons license for academic purposes only).

\section{Sketch 1}

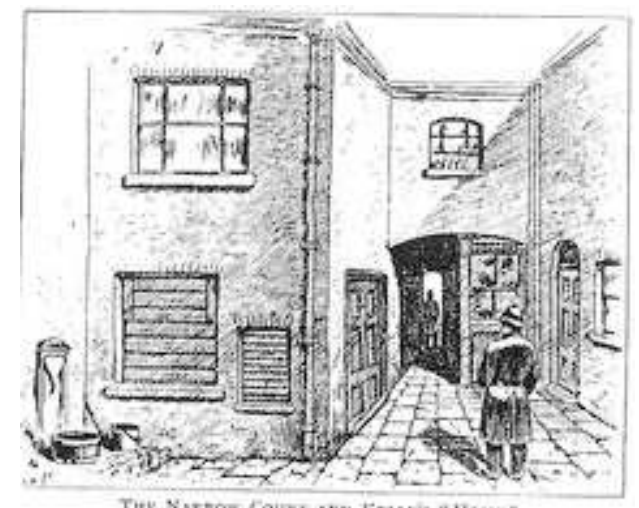

Miller's Court looking down the alleyway towards Dorset Street through the archway, on the corner are Mary Jane Kelly's rooms, first published in the Penny Illustrated Newspaper 17 November 1888.

Author's Note: On the street through the alleyway to the left was a shop where wheelbarrows were stored inside and homeless people sometimes slept the night in a shed. (No copyright clearance required as more than 50 years since first printed in a London newspaper). 


\section{BIBLIOGRAPHY}

References

Begg, P., Jack-the-Ripper : the facts, London, Portico, 2009.

Begg, P. \& Bennett, J., The complete and essential Jack the Ripper, London, Penguin, 2013.

Begg, P. \& Bennett, J, Jack-the-Ripper : the forgotten victims, Yale, USA : Yale University Press, 2014.

Begg, P., Fido, M. \& Skinner, K, The complete Jack-the-Ripper A to Z : The ultimate guide to the Ripper mystery, London \& New York : John Blake, 2015.

Bynum, W., Science and the practice of medicine in the nineteenth century, Cambridge, Cambridge University Press, 1994.

Casebook Jack-the-Ripper photo archive, at http://photos.casebook.org/, produced by Stephen P. Ryder et al.

Casebook Jack-the-Ripper victims, http://www.casebook.org/victims/mary_jane_kelly.html, http://www.casebook.org/victims/polly.html, produced by Stephen P. Ryder et al.

Coven, S., Slumming : sexual and social politics in Victorian London, Princeton, USA : Princeton University Press, 2006.

Craig, E. T., Phrenological chart, of the propensities, moral sentiments and intellectual faculties of the human mind, London, John Murray, 1845.

Craske, M., 'Unwholesome and pornographic : a reassessment of the place of Rackstrow's museum in the story of eighteenth-century anatomical collection and exhibition', Journal of the History of Collections, 2011, 23, I, pp. 75-99.

Daily Telegraph, 10 November 1888.

Davies, W. W., The real Mary Kelly, London, Blink Publ., 2015.

Evans, A., 'E.T. Craig : proto-socialist, phrenologist, and public health engineer', International Journal of Epidemiology, 2008, 37, III, pp. 490-505.

Evening Express, 12 November, 1888.

Fido, M., A history of British serial killing, London, Mortimer Books, 2011.

Green, D., Pauper capital : London and the poor law, 1790-1870, London, Ashgate, 2010.

Hurren, E. T., Dying for Victorian medicine : English anatomy and its trade in the dead poor, c. 1832 to 1929, Basingstoke, Palgrave, Macmillan, 2013.

Hurren, E. T., Protesting about pauperism : poverty, politics and poor relief in late-Victorian England, c. 1870-1900, Woodbridge, Suffolk : Royal Historical Society Series, Boydell and Brewer, 2015.

Hurren, E. T., Dissecting the criminal corpse : staging post-execution punishment in early modern England, Basingstoke, Palgrave Macmillan, 2016 (in press).

London Metropolitan Archives, A/FWA//C/D49, http://www.casebook.org/dissertations/wsprovidence.html.

MacDonald, H., Human remains : dissection and its histories, Yale, USA, Yale University Press, 2006. 
Marshall, T., Murdering to Dissect : Grave-robbing, Frankenstein and the Anatomy Literature, Manchester, Manchester University Press, 1996.

Old Bailey cases, http://www.oldbaileyonline.org/browse.jsp?div=t18580222-354_Crown versus Feist, 22 February 1858.

Porter, R., The greatest benefit to mankind : a medical history of humanity, London and New York, Fontana Press, 1999.

Porter, R., Blood and guts : a short history of medicine, London, Penguin, 2003.

Porter, R., Flesh in the age of reason; how the Enlightenment transformed the way we see our bodies and soul, London, Penguin, 2005.

Richardson, R., Death, dissection and the destitute : the politics of the corpse in pre-Victorian Britain, London : Wedenfield and Nicholson, 2001.

Rule, F., The worst street in London with a foreword by Peter Ackroyd, London, Allan, 2010.

St. Bartholomew's Hospital Archive, Dissection Records, MS1/1-6.

The Lancet, 29 September, 1888.

Trow, M. J., (2009), Jack-the-Ripper ; quest for a killer, London, Wharncliffe Books, 2009.

Walkowitz, J. R., City of dreadful night : narratives of sexual danger in late-Victorian London: women in culture and society series, Chicago, University of Chicago Press, 1992.

Walkowitz, J. R., Prostitution and Victorian society : women, class and state, Cambridge, Cambridge University Press, 1991.

White, J., London in the $19^{\text {th }}$ century: 'A Human Awful Wonder of God', London, Vintage, 2008.

Wise, S., The Italian boy : murder and grave robbery in 1830s London, London, Pimlico Books, 2005.

Wise, S., The blackest streets : the life and death of a Victorian slum, London, Vintage, 2009.

\section{APPENDIXES}

Appendices

\section{NOTES}

1. Selectively, refer to books by Fido (2011); Begg, Fido, and Skinner (2015); Begg and Bennett (2013); Begg and Bennett (2014).

2. Begg (2009, edition, p. 418).

3. Begg (2009 edition, p. 273).

4. See White (2008).

5. See, Green (2010).

6. Refer Hurren (2015).

7. Begg (2009, p. 275).

8. On Spitalfields \& Dorset Street, see, Rule (2010).

9. See, notably, Wise (2009, p. 18-24).

10. The geographical layout is covered in extensive detail at: http://www.casebook.org/ \& Jackthe-Ripper photo archive, at http://photos.casebook.org/. 
11. Notably, refer books by Walkowitz (1991) and (1992); Coven (2006).

12. Refer Richardson (2001) ; MacDonald (2006).

13. See Porter (1999).

14. Covered in Hurren (2013).

15. Begg (2009, p. 273).

16. Hurren (2013, p. 303) provides conservative figures for whole bodies and body parts in the conclusion to her book. She stresses that only whole cadavers had to be officially declared on death certificates ; body parts being traded were at least equal to, and more likely, exceeded that of, complete corpses bought and sold.

17. Ibid.

18. See Marshall (1996) for its history pre-dating the Anatomy Act (1832).

19. Refer Wise (2005, p. 10), points out that body dealers often congregated on Giltspur Street in a public house to collect and deliver their trades to St. Bartholomew's Hospital each morning after a night's trading.

20. St. Bartholomew's Hospital Archive, Dissection Records [hereafter SBHADR], MS1/1-6, 27 Oct. 1887 entry.

21. Ibid, MS1/1-6, 13 and 14 March 1888 entries.

22. SBHADR, MS1/1-6, 7 Dec. 1889 entry.

23. For the most credible and objective summary of all the key debates, see, Begg, (2009 edition).

24. Ibid, pp. 21-32, recounts the forensic facts.

25. Refer SBHADR, MS1/1-6 for example in 1834 had 9 well-documented cases of the "body have been opened" before being traded. A typical example was "Sarah West" a 63 year old female whose "abdomen had been opened" before being sold on in 1837. Another case is "Jane Sheriff' aged 60 sold from St Giles Workhouse on 2 December 1857 with "an opened body". She had been cut up by someone unnamed before death and then sold on as a damaged corpse.

26. Begg (2009, pp. 101-35).

27. Ibid, p. 79.

28. Begg, (2009, p. 135).

29. Lancet (29 Sept. 1888).

30. SBHADR, MS1/1-6, information in the marginalia of the register for 1840 .

31. Begg, (2009, p. 52).

32. Ibid, p. 78.

33. This case has been compiled from the online newspaper stories for her murder, available at : http://www.casebook.org/victims/mary_jane_kelly.html

34. Begg, (2009 edition, p. 482, footnote, 13 to chapter 16 on Mary Jane Kelly).

35. Refer footnotes 33 and 34 above, Ibid, pp. 267-313.

36. London Metropolitan Archives, A/FWA//C/D49, accessed 17/02/2015 at: http:// www.casebook.org/dissertations/ws-providence.html.

37. Begg (2009, pp. 267-313 covers the case in meticulous detail with quotes at p. 271).

38. See Porter (2003) and (2005).

39. Refer, Bynum (1994).

40. Context in Craske (2011, p. 75-99).

41. Begg (2009, p. 276).

42. Ibid, p. 267.

43. Begg (2009, p. 43).

44. Reported in Daily Telegraph 10 Nov. 1888 and Evening Express 12 Nov 1888; also cited in Begg, (2009 edition, p. 485, footnote 50).

45. Begg (2009, p. 486, footnote 50, to chapter 16, Mary Jane Kelly).

46. See, http://www.casebook.org/victims/polly.html, for primary sources relating to her life and these critically evaluated by Begg, (2009, p. 54-64). 
47. Trow (2009).

48. Old Bailey, Crown versus Feist, 22 February 1858.

49. Davies (2015).

50. Refer, Craig (1845) and Evans (2008, pp. 490-505).

51. Refer, Hurren (2016, in press), on dissection and phrenology under the Murder Act.

\section{ABSTRACTS}

Jack-the-Ripper has been an historical prism for international studies of crime, history and societies. This article re-examines the infamous violent homicides from a new medical perspective. In a cold case review, original evidence of a secret trade in the dead poor is presented, neglected in crime historiography. Trafficking in bodies and body parts to teach human anatomy to medical students was the norm in the East End of London in 1888. The business of anatomy - peopled by body dealers and their accomplices - had the medical infrastructure to provide a deadly disguise for the serial killings. Those that fell from relative to absolute poverty, in death, supplied dissection tables in major teaching hospitals across London. Its social wallpaper could conceivably have camouflaged homicide in the Metropolis.

$\mathrm{Au}$ plan international, la figure de Jack-L'éventreur a servi de prisme historique pour l'histoire sociale du crime. Cet article ré-examine ces homicides abominables et violents d'un point de vue médical nouveau. À partir d'une étude des affaires classées, l'article présente des preuves inédites d'un commerce secret de cadavres de pauvres, jusqu'ici négligé par l'historiographie. Le traffic des cadavres et de portions de ceux-ci destinés à l'enseignement de l'anatomie humaine pour les étudiants en médécine était la norme dans l'East End londonien en 1888. Le commerce anatomique, contrôlé par des trafiquants de cadavres et leurs complices, disposait de l'infrastructure médicale nécessaire pour camoufler les meurtres en série en morts naturelles. Ceux qui passaient de la pauvreté relative à la misère absolue, alimentaient après leur mort les tables de dissection des principaux hopitaux universitaires londoniens et il est fort possible que cette pratique ait permis d'occulter des homicides dans la métropole londonienne.

\section{AUTHOR}

\section{ELIZABETH HURREN}

Reader in the Medical Humanities in the School of History of the University of Leicester. She is renowned as an international scholar of the history of the body, with wide-ranging research interests in death, dying and poverty studies. In 2007 she published in the prestigious Royal Historical Society Series, Protesting about Pauperism : Poverty, Politics and Poor Relief in late-Victorian England. This was followed in 2013 by her ground-breaking study entitled Dying for Victorian Medicine : English Anatomy and its Trade in the Dead Poor, 1832 to 1929, short-listed in 2015 for the British Medical Association's Book of the Year Prize. In 2016, her latest book, now in press with Palgrave Macmillan, will be Dissecting the Criminal Corpse : Staging Post-Execution Punishment in Early Modern England. Elizabeth was editor of Wellcome History from 2012 and continues to be a board 
member of Family and Community History, as well as historical consultant for Historic Royal

Palaces, London. - eh140@le.ac.uk 